\title{
RADICAL TPACIPR
}

A SOCIALIST, FEMINIST, AND ANTI-RACIST JOURNAL ON THE THEORY AND PRACTICE OF TEACHING

Exorcising "Racecraft": Toward the RaceSyllabus

by Abena Ampofoa Asare
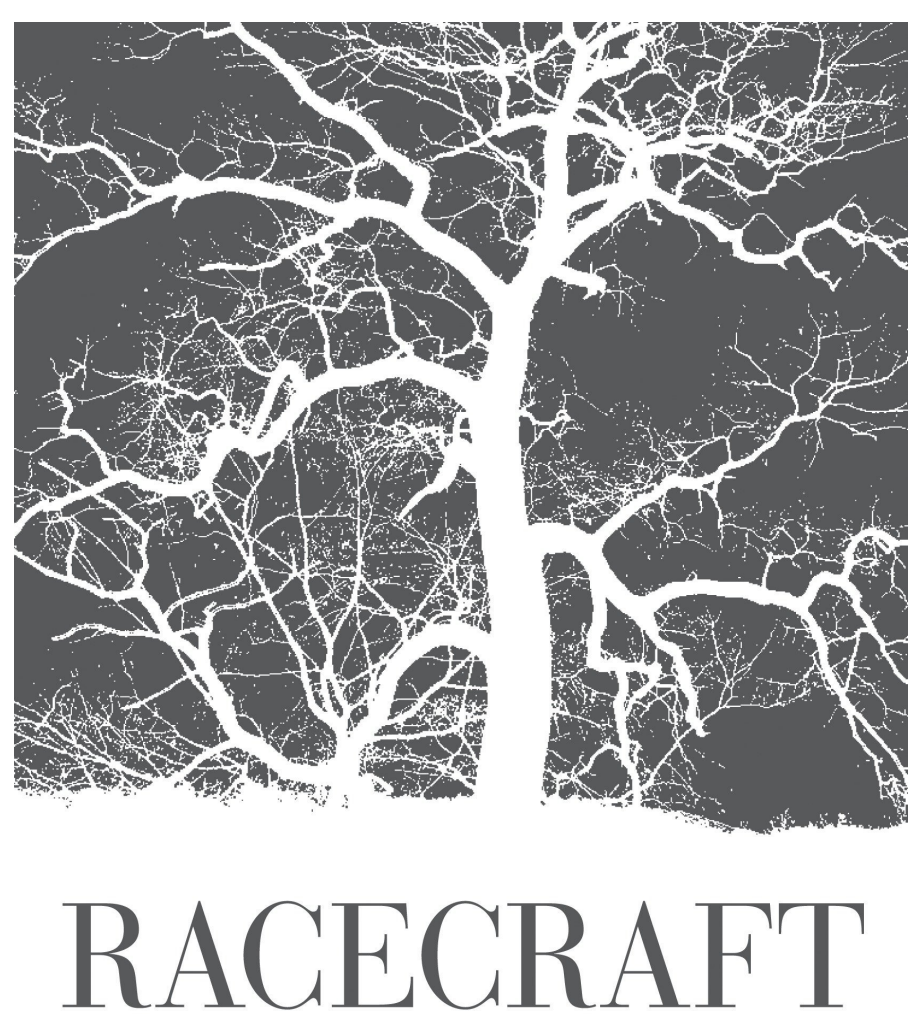

\section{The Soul of Inequality in American Life}

KAREN E. FIELDS AND BARBARA J. FIELDS 
$\mathrm{T}$ eaching effectively about race and racism in the American university is imperative; it is also notoriously difficult. ${ }^{1}$ The rise of crowdsourced and curated reading lists (\#Fergusonsyllabus, \#CharlottesvilleSyllabus, \#NoDAPLSyllabus) represents a public realization that those who hope to understand the manifestations of race and racism in twenty-first-century America must study; they must arm themselves with data and analysis extending beyond personal experience and anecdote. This new phenomenon is fundamentally optimistic; it stands on the hope that a collection of texts gathered together might make the United States' peculiar romance with race intelligible and thus penetrable. However, before students can get woke through these often interdisciplinary and rigorous reading lists, they must first understand what race is and what it is not.

This essay, based on my experiences teaching Africana Studies at a public university in the northeastern United States, argues the importance of a RaceSyllabus through which students grasp the artificiality of race as a manmade ideology that is neither biologically relevant nor divinely inspired. This term, Racesyllabus, is inspired by the phenomenon of crowdsourced and publicly accessible reading lists that valorize continual self-study as personally and politically necessary. ${ }^{2}$ Made for these strange times, when "a professed desire to be colorblind bumps up against the ubiquity of race consciousness, ${ }^{\prime 3}$ the RaceSyllabus is a curated series of readings designed to provide students with a critical analysis of race opposed to the common sense understanding of race as a reflection of an individual's biological makeup.

In Racecraft: The Soul of Inequality in American Life (2012), Barbara Jean Fields and Karen Fields coin the term racecraft to illuminate American society's continued attachment to a biological conception of racial difference despite the prodigious evidence that there is only one human race. ${ }^{4}$ Fields and Fields's language of racecraft harkens deliberately to witchcraft as a way of apprehending the subterranean, occult practices by which our national misconception of race is maintained. Race in America, they claim, is a folk religion; its home truths are located in a "middle ground between science and superstition...a half-lit zone in the mind's eye" that evades rationality and logic. ${ }^{5}$ Genetic diversity and similarity do not align with the social categories that we call race and yet we continue to structure our national life around this "taxonomy of ascriptive difference" by which we "construct populations as groups" and then "sort them into hierarchies of capacity, civic worth and desert." ${ }^{6}$ Perpetuating race requires an intermixture of practices and beliefs, ways of "acting and imagining [that] are collective and individual, day to day, yet historical, and consequential even though nested in mundane routine. ${ }^{7}$ Caught as we are in this twilight zone of racialism, Americans are particularly illequipped to struggle against racial injustice in ways that do not further enshrine the hegemony of race as a legitimate organizing principle. ${ }^{8}$ Undoing the prison of race as a social hierarchy requires battling racecraft's pervasive and occult knowledge; it involves illuminating that which is spoken and unutterable, challenging "truths" both visible and hidden. In short, it requires an exorcism.
In my teaching, I have developed a syllabus which propels students into a novel mental terrain where the racial categories we inherit and inhabit are neither inevitable nor natural, but instead are created and recreated by our national economic, political, social, and cultural choices. The RaceSyllabus supports two interrelated learning objectives that, together, encourage students to see outside our society's race-tinted lenses: 1) Students learn that that racial identities in the USA are historically specific; they encounter race as categories of identity that are created, policed, and re-created throughout our national history, and 2) Students learn that racial identities are geographically specific; they encounter different national frameworks where race is imagined and lived differently. These two simple insights, presented together, are remarkably effective in shaking diverse students free from the tentacles of a national racial myth whose power lies in its "vexing tendency to reproduce itself as history." ${ }^{\prime 9}$

The Racesyllabus is not a complete pedagogical tool. The texts I describe below could well be substituted with others which do the same work. Moreover, I am acutely aware that the success or failure of the RaceSyllabus is tied to the pedagogical strategies and assignments surrounding these texts. The reading list is only one factor in creating a classroom where, as Paulo Freire describes, "men and women develop their power to perceive critically the way they exist in the world with which and in which they find themselves."10 Navigating the psychological, emotional, and political landmines of race and racism in a classroom requires a challenging admixture of authenticity, comfortability and confrontation, voice and silence, revelation and interrogation. ${ }^{11}$ Indeed, a herculean pedagogy of emotional, physical, and spiritual engagement-a classroom where "students and teachers talk, laugh, cry, hold hands, sing, clap, role-play, and organize rallies and teach-ins" may be required. ${ }^{12}$ And yet, this paper does not dwell on my own pedagogical praxis; I do not describe the shifting strategies I employ to create a classroom marked by student engagement, accountability, and leadership. ${ }^{13}$ Nor do I explore the way that my perceived identities (West African/American, woman, cisgender, stammering) may affect student experiences. ${ }^{14}$ I have excluded these factors not because I do not think them important. On the contrary, my focus on the Racesyllabus is a deliberate attempt to invite diverse educators, using varied pedagogical strategies, to consider how a basic aspect of their course - the reading list-may aid (or impede) students' ability to grasp the artificiality of race categories.

The northeastern public university where I developed the RaceSyllabus ranks far above the national average for an ethnically diverse student body. More than half of the students identify as Asian, Hispanic/Latino, Black/African American, or foreign nationals. In addition, more than onethird of the students are eligible for Pell Grants and many of the students that take my classes are the first in their family to attend college. Partnership with these particular students honed the RaceSyllabus and convinced me of its significance. My classroom on any given day may include a young woman born in Brooklyn and raised in Guyana by 
her grandmother, a religious Pakistani-American student attending a mosque staffed by an African American imam, the grandchild of an African American woman from Savannah, Georgia who moved to New York as part of the Great Migration, a Japanese student living in Saudi Arabia, the granddaughter of an Italian immigrant who came to Ellis Island in the early twentieth century, the daughter of a undocumented Salvadoran small business owner, and the grandchildren of Russian Holocaust survivors. Even among these students-exceedingly diverse in almost every way including citizenship status, ethnicity, class, nationality, color, and creed- the consequences of our national romance with a biological notion of race are evident.

Over the past seven years of teaching, I have observed that racialism persists even among twenty-firstcentury students. Born almost fifteen years after the passage of the US Civil Rights Act and the Fair Housing Act (1968), Millennials grow up in a context where racial integration, however limited, is a social ideal. Steeped in images of racial tokenism and living in times where "racist" is a slur denoting ethical failure or anachronistic belief, Millennials are more socially open than previous generations and are, supposedly, the answer to the USA's racial nightmare. However, this hope that interracial friendships and diverse music collections will ensure national political and sociological transformation reflects a profound misunderstanding of how racism is reproduced in twenty-first-century America.

Although modern science tells us that inherent differences between people classified as racially separate do not exist, our society has made race a proxy and determinant of myriad social, economic, and physical outcomes. Alternatively, although genetics tells us of biological similarities and relationships between people who share genetic material, these genetic pools do not neatly align with our racial classification categories. Our national context blurs the above distinctions. As a result, students cannot help but believe there is some truth to the myth of racial difference, even if they believe it impolite to mention such.

Most Millennial youth (like their parents) remain constrained by racecraft, even as they resist the idea that it is acceptable to treat individuals poorly because of racial identity. Their visions of future justice are rooted in the assumption that there are probably essential distinctions between people who are grouped as Black, White, Asian and Latino, although they hesitate to delineate particularly what these are. We should not be surprised by this; most of the instruction about race and racism that most students encounter before (and during) university is filtered through a diversity framework which has been roundly excoriated as "devoid of historicity" and able to do very little to transform "essentialist readings" of racial identity. ${ }^{15}$ The persistence of racecraft in the twenty-first-century USAeven among diverse Millennial youth-inspired my efforts to create a course highlighting the construction of race categories across time and space.

The RaceSyllabus works to collectively undermine the notion of race as self-evident in our bodies, thus disorienting students who subscribe to the common-sense belief that racial identity is an objective or neutral identity marker. In this paper, after mapping the contours of twenty-first century racecraft and describing the content and objectives of the RaceSyllabus, I reflect on the impact of these readings on a population whose experiences in undergraduate courses on race is often overlooked and taken for granted: Black and/or African-American students.

\section{The Persistence of Racecraft}

Teaching that race is a social construction with limited biological utility is a mantra within social science classrooms. ${ }^{16}$ However, for many students, the social construction model seems to conflict with everything they have previously known. Their science textbooks have, most likely, connected race with biology in both "tight and loose linkages" which ultimately "preserve the cultural authority of the race concept." ${ }^{17}$ Moreover, students are influenced by our current "genomic turn," where the dribs and drabs of genetic theory filtering into the public sphere coyly suggest that racial identities may indeed be located in our DNA. ${ }^{18}$ If race-as-biology seems to be getting a new lease on life today this is because the public consensus against this framework was never particularly solid. In a classroom of true believers who insist that race is a social construct --anthropologists, sociologists, historians and the like- many students may struggle to grasp this idea, even as they parrot back the phrase. ${ }^{19}$ It is no coincidence that Barbara Jean Fields and Karen Fields, respectively an historian and a sociologist, write Racecraft self-consciously as educators. The analytical limitations created by racecraft are most evident in those spaces where critical thought is supposed to reign-in U.S. classrooms.

An interdisciplinary community of scholars continues to wrestle with the challenge of rooting out race's biological pretensions in their teaching. Historian Linda Gordon laments her attempts to deconstruct race among predominantly European American undergraduates who saw her attempts as a perverse "denial of observable physical differences."20 Similarly, anthropologist Katya Gibel Mevorach describes prohibiting her students from using the word race as a noun. If students always use race as a verb (i.e. communities and individuals do not possess a racial identity, they are raced) they may train their tongues and consequently their minds into perceiving the social labor that is always a part of racial identification. ${ }^{21}$ When students assimilate this teaching of race as social construct as yet another of academe's curious mores -perhaps intellectually astute, but with little to no practical relevance- what, then, is to be done?

When students assimilate this
teaching of race as social construct
as yet another of academe's curious
mores -- perhaps intellectually
astute, but with little to no practical
relevance- what, then, is to be
done?


The tenacity of biological notions of race has compelled educators to develop particular classroom activities to combat the status quo. Sorting exercises, where students are presented with visual images of human beings of diverse phenotype and asked to sort them into races, are supposed to distance students from a commonsense understanding of race. ${ }^{22}$ By struggling to sort the pictures of "racially ambiguous" persons (i.e. Adam Clayton Powell, Walter White, and Dwayne "The Rock" Johnson), students are supposed to recognize the limitations of our racial categories. However, these sorting exercises actually do very little to challenge the logic of racial categorization. They may further entrench the power of race-thinking by confirming to students that there are "right" and "wrong" ways to sort people, notwithstanding the few individuals whose ambiguous bodies supposedly place them on the margins of this classification system and make their "correct" racial identity difficult to ascertain. Persons of supposedly mixed heritage become the exception that proves the rule. These sorting exercises rarely lead a European American student to ask, "if Adam Clayton Powell is Black, might I not then also be Black?" Neither do sorting exercises prompt a Bangladeshi-American student to ponder the irrationality of the Asian box's blithe insistence that there is an inherent connection between herself and her colleagues from Tonga, Korea, and Northern China.

Although some forms of racism have become taboo, race ideology - which bestows on an illogical, unstable, and irrational system of human categorization the mantle of truth- has not been supplanted. ${ }^{23}$ Two recent examples are useful for considering the way race-thinking shades the vision of even those who passionately desire to combat the scourge of racism.

1. A middle-school teacher came to me to criticize her colleagues, European American women like herself, for seeking to hold a classroom of predominantly African American and Latinx students to what she called "White middle-class norms." "They have to understand that these Black and Latinx families don't share these norms, nor should they be made to," she insisted with much exasperation. For my colleague, completing nightly homework, investing in music lessons, and attending parent-teacher conferences were "White middle-class" norms. Across a presumed racial divide she assumed her Black and Latinx students held other norms. Precisely what these "other" racial norms regarding education actually were (tardiness? non-investment in extra-curricular enrichment?) was never articulated. This educator believed herself to be working against racist exclusion in the classroom. However, her insistence on assigning particular behaviors a racial identity, and then reading the bodies of her students as a cipher for their behavior, is the essence of racecraft.

2. In March 2017, Moises Velazquez-Manoff published an opinion article in The New York Times entitled "What Biracial People Know." This article asserts the inevitability of U.S. racial progress based on a demographic argument about the expanding biracial/multiracial population; supposedly, "mixed-race" people are more likely to "construct a worldview that transcends the tribal." 24 This prediction that sexual relationships and multiracial families will be the coffin for racial injustice is popular among undergraduates every semester - it is also a particularly nefarious expression of racecraft. The argument about "what biracial people know" is a simple update of the nineteenth- and early twentieth-century trope of the tragic mulatto. Instead of "mixed blood" producing an unsettled mind and doomed destiny, here, mixed blood is the harbinger of a more advanced consciousness. At core, this argument is based on a pseudoscientific superstition that by possessing racially-ambiguous bodies, multiracial persons are somehow the bearers of an alternative consciousness. In reality U.S. history is replete with "multiracial" persons, both past and present, who have not been advocates of racial equality and who, based on their socialization, have been conduits of racist exploitation. In 2018 as in 1898, the idea that "racial mixing" (a term that in and of itself assumes the biological reality of racial categories) produces any particular type of human being is rooted in the superstitions surrounding race.

\section{Even those who abhor racism may take for granted the solidity of our racial categories.}

I have chosen both of the above examples to show the wiliness of racecraft; even well-meaning persons who would hope to be among the architects of a more equal society may find themselves espousing a biological concept of race and suggesting that there are fundamentally different types of human beings who can be known and sorted according to miscellanea of phenotypical features including skin color, hair texture, nose shape, skull size, and genitalia. Even those who abhor racism may take for granted the solidity of our racial categories. I do not use the word exorcism lightly but specifically, to communicate the difficulty of casting out race ideology from among us.

The troubling persistence of racism has spurred new efforts to apprehend (and mourn) our socialization into the harmful practices by which racial inequality is maintained and preserved. The burgeoning research on "implicit biases" trumpets what the families of Amadou Diallo, Mike Brown, Philando Castile, and countless others have long known: the occult power of racecraft in our minds and institutions is not innocuous. Thinking race, for many of us, equals thinking and doing harm. Our subconscious minds, whose "processes of social perception, impression formation, and judgment" we do not always control, have almost certainly been corrupted by violent race ideologies. ${ }^{25}$ Unfortunately, this implicit bias research has led many to conclude that the violence of our mindshooked-on-race is unavoidable. ${ }^{26}$ What are we to do with the "unhappy ordinariness" of implicit bias and the resulting discriminatory behaviors and institutions? ${ }^{27}$ Supposedly, new policies and procedures will limit the damage done by our covert beliefs about race. And so preschool teachers are instructed to speak with empathy when disciplining Black students; health care professionals are invited to "double-check" themselves when listening to Black women in their care; and legal experts seek to 
challenge the idea that intention and animus must be central to discrimination cases. ${ }^{28}$ With all due respect to these pragmatic efforts to limit the harm caused by negative judgments, perceptions, and associations, attempting to change our practices without changing our minds will not free us from our racist national history. Constant education and re-education about the history and sociology of race in America and beyond is fundamental to anti-racism.

\section{The RaceSyllabus}

The first part of the RaceSyllabus explores how race categories in United States history have been defined and redefined over time, and according to particular imperatives. These texts expose the historical processes through which different groups of people -- African American, European American, Native American, and Asian American-have been assigned a racial identity at different moments in the American past. Using primary and secondary sources, students begin to perceive that identity is far from obvious, biologically apparent, or inevitable; and instead has been established, policed, and reinforced by individuals and institutions according to economic and political directives.

The course begins by challenging the imagination of Blackness as an essential and eternal category through Barbara Fields's "Slavery and Race Ideology," and the introduction to Yaba Blay's One Drop: Shifting the Lens on Race. ${ }^{29}$ By tracing the laws and practices used to determine who was defined as Black and why, these authors explore the violence through which enslaved Africans and their descendants were made into a caste apart. Faced with these texts, my students wrestle with the economic incentives that shaped how Blackness was defined and redefined in American history. Students hear, often for the first time, that the racist laws that created slavery and Jim Crow were not natural reactions to skin color differences, but instead were contingent, chosen policies to consolidate and create economic and political power. Both those students who view racism as a personality disorder akin to bullying, and the others who believe in anti-Black racism as eternal and inevitable, are challenged by this discussion of the particular construction of Blackness. After all, if racism has been constructed through law, land ownership, employment, and wealth creation, it may also be deconstructed.

As Blackness has been constructed, so has Whiteness; subsequent texts explore the invention and re-invention of Whiteness as an exclusive marker of full citizenship. One of the innovations of Whiteness Studies has been to show that a status with pretensions of permanence and inherence is anything but. Many undergraduate courses teach about "white privilege" a la Peggy McIntosh's famous "invisible knapsack" of psychosocial, economic, and political benefits, but few delve into the ways disparate groups of American have attained Whiteness. I have observed undergraduate students contemplate shifting definitions of Black identity without batting an eye, and then gape and sputter in disbelief when confronting the idea that Whiteness, their Whiteness, may have been questioned at some other time in US history. The essays from Jennifer Guglielmo and Salvatore Salerno's Are Italians White: How Race is Made in America and excerpts from Matthew Frye Jacobsen's Whiteness of a Different Color: European Immigrants and the Alchemy of Race, are necessarily and powerfully disorienting for European American students who declare-sometimes with regret, other times with pride- their Whiteness as an incontrovertible fact.

The third episode of the PBS documentary Race: The Power of an Illusion reveals the U.S. Supreme Court as a site in which Whiteness was constructed and policed. Two court cases, Ozawa v. United States (1922) and U.S. V. Bhagat Singh Thind (1923), reveal the machinations of legal racecraft. Both Takao Ozawa, a Japanese American, and Bhagat Singh Thind, an Indian American, were denied U.S. citizenship because the Supreme Court declared them ineligible for naturalization under the 1906 law that made race a factor in citizenship. The Court used the scientific racism of the day to argue that Takao Ozawa was not Caucasian and thus not White, but balked when Bhagat Singh Thind sought to use scientific racism to argue that he, too, was White. Thind presented evidence connecting "Indo-Aryan" languages and cultures of South Asia to Europe and claimed, with the support of scientific authorities, that he was of "pure Aryan blood." The US Supreme Court quickly abandoned the logic of scientific racism when it seemed it could be used to pry open the boundaries of Whiteness; Thind might very well be Aryan, the Court concluded, but he could never be White because the "common White man" would never recognize him as such. The PBS film is particularly useful because it carries the discussion of Whiteness up to the present day by showing how housing and geographical segregation in the post-World War II era continue to transfer and allocate benefits along racial lines, and thus consolidate White identities.

The next set of readings explores the racialization of Native American identity in US history. M. Annette Jaimes's Sand Creek: The Morning After describes the genocidal consequences of settler colonialism and manifest destiny; Eva Garroutte's Real Indians considers the history of the blood quantum standard and the role of the US federal government in delimiting the substance and boundaries of American Indian identity. Exposing the perverse logic of a federal government that embraced the one-drop rule for African American populations and the opposite logic of blood quantum to Native American communities leads to a fruitful conversation about why, in the words of indigenous scholar Jack Forbes, modern Americans are "always finding 'blacks' even if they look rather un-African, and are always losing 'Indians."'30 Confronting settler colonialism and the economic value of the narrative of Native American disappearance propels students beyond the Black-White dyad and leads them to confront the breadth of racial injustice in the American story by connecting, not only comparing, different histories of racialization.

Considering Asian Americans as a racialized group is particularly important for Millennials who have been fed a steady diet of Asian exceptionalism suggesting that the 
diverse immigrant communities from Asia and their descendants have no place in the hue and cry of US racial history. Stacey J. Lee's research interrogates how the model minority stereotype obscures histories and experiences of difference within the expansive community racialized as "Asian" in America. ${ }^{31}$ Moreover, Natsu Taylor Saito's "Model Minority, Yellow Peril: Functions of Foreignness in the Construction of Asian American Legal Identity" highlights a history of legal and social exclusion against Asian immigrant communities, and the economic, cultural, and social anxieties entangled in contemporary stereotypes of Asian Americans. ${ }^{32}$ Featuring the movie Yuri Kochiyama: Passion for Justice, this section invites students into a discussion about anti-racist solidarity, respectability politics, and the hidden heroes of the civil rights era. For my diverse students, analyzing the life and politics of an Asian American woman activist is a new experience, one that may lead them to confront their own assumptions and stereotypes.

The second section of the RaceSyllabus explores how race ideology shifts across geographical space. Considering how race is understood and defined differently across national borders is perhaps the most effective way for students to perceive the limitation of racial frameworks hitherto perceived as inevitable or universal. A unit on the racialization and displacement of Australia's aboriginal communities explores the racial legacy of settler colonialism beyond the USA. The history of indigenous people, racialized as barbarous "blackfellas" is an important point of comparison to US history. Rolf De Heer's 2002 film The Tracker, coupled with teaching about the Australian Freedom Rides, the Wave Hill Walk Off, and the Bring Them Home Report, invite students to consider that although settler colonialism, racialization, and resistance are global phenomenon, the consequences have been different in various locales. ${ }^{33}$

Next, readings about the Dominican Republic (DR) introduce students to the complexity of national racial regimes forged in the interstices of local and global histories. The DR, with its intricate and complicated system of classification based on phenotype, wealth, and status, is only intelligible within a longer history of Spanish imperialism, in relation to neighboring Haiti's unparalleled history of slave revolution, and with an understanding of both dictator Rafael Trujillo's political violence and the lopsided regional economy that gave rise to the Washington Consensus. Henry Louis Gates, Jr.'s film Race in Latin America, coupled with Ernesto Sagas's "A Case of Mistaken Identity: Antihaitianismo in the D.R.," introduces students both to the difference created by Dominican nineteenth- and twentieth-century history and more recent political events shaping how race is used for nationbuilding among Dominicans both at home and abroad. ${ }^{34}$

Finally, selections from Mohammed Adhikari's seminal text, Burdened By Race: Coloured Identities in Southern Africa, explores the centrality and modalities of racialization in South African apartheid, particularly the political, economic, social, and psychological consequences of the creation of a "Coloured" class. Together these texts reveal the global proportions of the race dilemma and its rootedness in particular national and regional histories. The inclusion of a few readings illuminating the transnational production of racialized consciousness, such as Evelyn Yakano-Glenn's "Yearning for Lightness," about the global market for skin lightening agents, and L. Ayu Saraswati's "Malu," about the impact of migration, colonialism, and globalization on colorism in Indonesia, allow students to consider the ways national racial regimes are often influenced by and constitutive of a broader globalized modernity which holds and transmits particular values about racial difference. ${ }^{35}$

When I teach the RaceSyllabus I pair the readings above with a culminating oral history project that urges students to take their critical lens on race and race-making from the realm of text and apply it in the world. In this project, students seek to understand the multiple factors (historical, geographic, familial, etc.) that have shaped a single individual's understanding of racial difference and racial identity. By choosing an elder over the age of 55developing a set of questions designed to uncover how a person's consciousness about the nature, boundaries, and experience of race has been formed and transformed, asking the questions and listening for the answers, and finally, analyzing the stories, silences, stereotypes, convictions, fears, advice, and assumptions that arise in the space between the interviewee and interviewerstudents begin to utilize, parse, challenge, and test the analytical value of the RaceSyllabus's expanding understanding of race in their own community. In considering the local, national, and international events, familial dynamics, sociological scripts, and cultural frameworks that have shaped the racial consciousness of diverse individuals, students step firmly outside the common-sense understanding of race as skin color and biology.

\section{Disorientation and Exorcism}

In this section, I offer some preliminary thoughts about the RaceSyllabus's impact on undergraduate students of African descent (African American, Afro-Latinx, Caribbean American, and first generation African students). These are students of diverse backgrounds racialized as Black within the US political, social, and economic order. There is abundant research and discussion on the benefits accrued by White students who attend classes that challenge the status quo's centering of Whiteness as universal. ${ }^{36}$ However, what do classes on race offer "those [students] most marginalized by structures of race, gender, sexuality, and capitalism"? ${ }^{37}$ The scholarly inattention to Black-identified students' experience of race pedagogy is part of a deeper silence on the intellectual trajectories of students of color (apart from graduation rates, grade point averages, etc.) within American universities. ${ }^{38}$ Emerging from my experiences as a college instructor and previously as an undergraduate and graduate student, the observations below are a step toward closing this gap.

Undergraduate courses about race in predominantly White institutions are often geared to an assumed European American audience that needs to be cajoled, persuaded, and educated about the reality of racial 
discrimination and urged toward greater inclusion. ${ }^{39}$ In these courses Black students are expected to function as expert and authentic voices that bring to life and affirm the insights of the instructor. The "good Black student" offers anecdotes that confirm the presence of racism and assist the instructor in bringing the good news to her classmates. There are many problems with this model, the first being that many students of color harbor, believe, and repeat the Eurocentric dictums that are pervasive in our collective national culture. ${ }^{40}$ Expecting Black students to act as surrogate experts by dint of their assumed experience often does not result in significant analytical growth for the students placed in the spotlight nor the class as a whole. This is also a problem because Black students are, essentially, paying for a class where their bodies and lives are being used as supplementary texts. They are often not given the privilege of acting as students in these classes and instead are required and/or burdened to keep the class in check by sharing their stories, displaying their anger and/or tears, or by being calming presences at the appropriate time. ${ }^{41}$ In these classes, Black students' labor goes unrecognized and is often misunderstood as leadership. Moreover, they are given neither a curriculum nor the intellectual space to grow in their understanding of racial injustice. Black students' educational needs may be "rendered invisible" in classes supposedly focused on race and injustice. ${ }^{42}$

\section{Expecting Black students to act as surrogate experts by dint of their assumed experience often does not result in significant analytical growth for the students placed in the spotlight nor the class as a whole.}

The RaceSyllabus veers away from this model where Black students are expected to function as the resident experts. The syllabus is intellectually destabilizing, by design, for all students. Including sociological, literary, historical texts about the African American, Native American, European American, and Asian American experiences in the same course disrupts the dynamic where Black students are expected/allowed to "know it all" and to lead White students toward greater understanding. The average undergraduate student, of any background, does not enter the class understanding the nuances of how race has been constituted and reconstituted; they have not yet contemplated the importance of the New Orleans exception to the rule of hypodescent or the importance of the Sand Creek Massacre and its relation to the blood quantum racialization of American Indian communities. They have not yet been taught about the relationship between Takao Ozawa's Supreme Court case and the Japanese-American Internment, or the relationship between the model minority myth and the obstacles to anti-racist solidarity. This breadth is not a matter of including different voices; it is a necessary part of tracing the complexity of how race functions as a national ideology in the USA. This intellectual disorientation is often necessary when inviting students into a posture of learning.

For some Black students it may initially be disconcerting to participate in a race class where they are not expected to serve as co-teachers. For others, denaturalizing the racial identities that are second skin for all of us in the USA carries with it psychic risk. This teaching that Blackness, too, has been artificially constructed may seem to trivialize what many of us knowthat Black identity and community has been as a balm in Gilead, a way to survive and thrive despite atrocity. The admixture of struggle, genius, joy, and strength that Black communities have called heritage is a sacred patrimony that we, living in hostile climates, would be foolish to deconstruct away. ${ }^{43}$ We must not overlook the possibility that racecraft, like witchcraft, has different purposes; that which kills may also cure.

Black identity has, historically, existed in excess of the violence that it justified. Forming a race, a community out of the linguistically, culturally, religiously disparate peoples in the hold of a schooner traversing the Atlantic Ocean's Middle Passage was a means to preserve culture, assert humanity, and survive a hostile and violent New World. ${ }^{44}$ While European American slave society was busy creating Blackness as the epitome of inferiority through laws and practices of terror, enslaved persons were also forging Blackness as a way to pursue that which had been lost: the home place. Blackness is simultaneously a "concept [that] originated from without," and a concept that racialized communities transform in ways that threatened the very foundations of the host society. ${ }^{45}$ The mantra of race-associal-construction rarely takes into account the way that Blackness has been co-created, differently, by those who would oppress and those who would be free. When Black students are asked to deconstruct the framework of race, it may appear to them as a rejection of the solidity of Black identity and Black community.

However, the exorcism initiated by the RaceSyllabusthis process of holding our national categories at arm's length and worrying the painful patchwork of how and why communities have been racialized-- does not require that we valorize a future that is disconnected from the past. Discarding the biological myth of race need not be a step toward the regressive popular ideology known as colorblindness. The colorblind ideal champions a baffling notion that ignoring a history of racial violence and its many legacies will somehow make racism disappear. On the contrary, exorcising racecraft requires that we plunge deeper into our history in order to understand exactly how, when, and why race has been marshaled for various political, economic, and social ends. Yes, realizing that these identities are not biological or divine is disorienting; it is also an opportunity to consider how and why race remains so powerful today, both as a site of discrimination and a source of resistance. What, pray tell, is the genetic relationship between the descendants of Khoi-San peoples in South Africa, Nigerian immigrants living in Houston, and an African American man who traces his roots to Florida's indigenous and enslaved populations? All are Black in America and will be treated as such by their health care providers, teachers, and police officers. This is how the 
RaceSyllabus finds its footing with Black students. As students become disoriented from a common-sense identification with Blackness, they have the chance to articulate that which they have always known: that there are clear limits to the vision of community rooted in this thing called race. In classrooms like mine which often represent the breadth of the African diaspora, the idea of singular Black culture dissolves under the lightest pressure. Considering what remains of racial identity once the biological myth is discarded, students begin to consider Blackness as an identity that is chosen by society and individuals in the past and present, for disparate ends. Moving from the framework of race as inevitable towards the realization of race as historically created allows students to perceive how race is still being made and remade in their own lives.

I have observed the value of this reassessment among Black students who enter the class burdened under an avalanche of statistics about Black failure (overrepresentation in prisons, the "achievement gap," the "wealth gap," HIV/AIDS rates, etc.) that are presented without any concurrent discussion about racism. ${ }^{46}$ For Black youth, the impact of this barrage of disparity statistics may be a sneaking suspicion that there is something fundamentally lacking or broken about their families, their communities, or themselves. Ibram X. Kendi has recently traced the longevity and persistence of ideas claiming that racial inequality is based on Black pathology and the diverse, multiracial, and multicultural interlocuters who continue to espouse "cunning, close-minded and captivating" ideas of racial inferiority. ${ }^{47}$ Illuminating racecraft by shining a light on the social, economic, and physical violence which has previously been misconstrued as nature and biology is crucial for all students, but it may be particularly empowering for those Black students who often suffer the psychic costs of our national mythology of racial difference.

\section{Conclusion}

This essay is based on the premise that undermining the American myth of race as biology and destiny remains necessary labor. I have described the contents of a RaceSyllabus that explores first the instrumentality of race in US history and, second, the difference in how race is understood in various nations and communities. These two teaching points, taken together, are remarkably effective in dislodging the common-sense understanding of race as an inherent category of human difference. The RaceSyllabus reveals the pervasiveness of racecraft; it is geared toward diverse students who believe that the prevailing racial categories, the boxes we check on federal forms, are something other than the artifacts and evidence of a national history of racial genocide, violence, and exclusion.

Following Fields and Fields's delineation of racecraft as the practices and beliefs used to produce and reproduce this myth of race as biology and destiny, I describe the work of the syllabus as an exorcism. Humans may have invented race but it is an ideology which now seems to possess us, making of our minds a prison and a mockery of our best intentions. Carrying with it a judgment about the malignancy of the unexamined race framework, the language of exorcism speaks to the harm associated with the race framework, and also of the need to battle this affliction in multiple realms.

After all, ours is a country which assigns wildly disparate opportunities and challenges to infants of different racialized communities and then spends endless resources and time wringing our hands, seeking to locate pathology in the communities which are negatively racialized, and stubbornly averting our eyes from our institutions (criminal justice, education, land access, media, housing, etc.) that ensure that groups racialized as inferior have violent experiences of citizenship. The lack of public outcry about accelerating school resegregation, about the prison industrial complex, or about charter schools that suggest that poor Black and Brown students may access quality education as a matter of lottery, is perhaps the clearest evidence of our prevailing belief that different communities deserve different life trajectories.

Exorcizing racecraft is a dis-possession; casting out racial essentialism requires casting off particular ways of seeing, understanding, and moving through the world. There is a loss for those who seek to think and live apart from the folk religion of race; "either you must pay the epistemic price of failing to encode certain sorts of baserate or background information about cultural categories, or you must expend epistemic energy regulating the inevitable associations to which that information... gives rise. ${ }^{\prime \prime 8}$ Rejecting racecraft requires that we live in a state of non-alignment with our national political and social order; there are costs to seeing and living outside the racetinted lenses of our national collective vision. And yet, every spring semester, I vigorously teach the RaceSyllabus because I believe that this exorcism and the accompanying disorientation and non-alignment are emancipatory for diverse students. Those who would dream of a world beyond racial violence must first be able to see through race. 


\section{Notes}

${ }^{1}$ Joyce E. King, "Dysconscious Racism: Ideology, Identity and the Miseducation of Teachers," Journal of Negro Education 60, no. 2 (Spring 1991): 133-46; Manning Marable, "Black Studies and the Racial Mountain," Souls 2, no. 3 (2000): 17-36; Karen Brodkin, Sandra Morgen, and Janis Hutchinson, "Anthropology as White Public Space?," American Anthropologist 113, no. 4 (December 1, 2011): 545-56, https://doi.org/10.1111/j.15481433.2011.01368.x; Frances V. Moulder, "Teaching about Race and Ethnicity: A Message of Despair or a Message of Hope?," Teaching Sociology 25, no. 2 (1997): 120-27, https://doi.org/10.2307/1318657; Helen Fox, "When Race Breaks Out": Conversations About Race and Racism in College Classrooms, Revised edition (New York: Peter Lang, 2014).

2 "Teaching Trump: The Rise of the Crowd-Sourced Syllabus," JSTOR Daily (blog), December 1, 2016, https://daily.jstor.org/teaching-trump-rise-crowd-sourcedsyllabus/.

${ }^{3}$ Michael Omi and Howard Winant, Racial Formation in the United States, 3rd edition (New York: Routledge, 2014), 2.

${ }^{4}$ Barbara J. Fields and Karen Fields, Racecraft: The Soul of Inequality in American Life (New York, NY: Verso, 2012).

${ }^{5}$ Fields and Fields, 23.

6 Adolph Reed, "Marx, Race, and Neoliberalism," New Labor Forum 22, no. 1 (2013): 48.

${ }^{7}$ Fields and Fields, Racecraft: The Soul of Inequality in American Life, 19.

${ }^{8}$ Omi and Winant, Racial Formation in the United States, 2.

9 Stephan Palmié, "Rejoinder: Genomic Moonlighting, Jewish Cyborgs, and Peircian Abduction," American Ethnologist 34, no. 2 (2007): 245-51.

10 Paulo Freire, Pedagogy of the Oppressed (New York: Herder and Herder, 1971).

11 William Ayers, Jean Ann Hunt, and Therese Quinn, Teaching for Social Justice: A Democracy and Education Reader (New York, NY: The New Press, 1998).

12 Ralph Armbruster-Sandoval, "Is Another World Possible? Is Another Classroom Possible? Radical Pedagogy, Activism, and Social Change," Social Justice 32, no. 2 (100) (2005): 35.

13 Aristotelis Santas, "Teaching Anti-Racism," Studies in Philosophy and Education 19 (2000): 353.

14 See the following texts about the significance of instructor identity and race pedagogy: Kamini Maraj Grahame, "Contesting Diversity in the Academy: Resistance to Women of Color Teaching Race, Class, and Gender," Race, Gender \& Class 11, no. 3 (2004): 54-73; Chavella T. Pittman, "Race and Gender Oppression in the Classroom: The Experiences of Women Faculty of Color with White Male Students," Teaching Sociology 38, no. 3
(July 2010): 1, 183-96, https://doi.org/10.1177/0092055X10370120.

15 Mariela Nunez-Janes, "Diversity as an Orientalist Discourse," Ethnic Studies Review 30, no. 1/2 (Winter 2007); Arjun Appadurai, "Diversity and Disciplinarity as Cultural Artifacts," in Race, Identity and Representation in Education (Routledge, 2013).

16 Jennifer Gilroy Hunsecker, "Teaching About Race in Introductory Anthropology Courses: An Ethnographic Study" (University of South Florida, 2015), http://scholarcommons.usf.edu/cgi/viewcontent.cgi?article $=6698 \&$ context $=$ etd.

17 Ann J. Morning, "Reconstructing Race in Science and Society: Biology Textbooks 1952- 2002," American Journal of Sociology 114 (2008): 106; Ann Morning, "Reconstructing Race in Science and Society: Biology Textbooks, 1952-2002," AJS; American Journal of Sociology 114 Suppl (2008): S106-137; Okay Odocha, "Race and Racialism in Scientific Research and Publication in the JNMA," Journal of the National Medical Association 92, no. 2 (February 2000).

18 Stephan Palmié, "Genomics, Divination, 'Racecraft'," American Ethnologist 34, no. 2 (2007): 205-22; Alan H. Goodman, "Toward Genetics in an Era of Anthropology," American Ethnologist 34, no. 2 (2007): 227-29; Nadia Abu El-Haj, "Rethinking Genetic Genealogy: A Response to Stephan Palmié," American Ethnologist 34, no. 2 (2007): 223-26.

19 Hunsecker, "Teaching About Race in Introductory Anthropology Courses: An Ethnographic Study," 140; Brian K. Obach, "Demonstrating the Social Construction of Race," Teaching Sociology 27, no. 3 (1999): 252, https://doi.org/10.2307/1319325; Nikki Khanna and Cherise A. Harris, "Teaching Race as a Social Construction: Two Interactive Class Exercises," Teaching Sociology 37, no. 4 (2009): 369.

20 Linda Gordon, "Who's White?," The New York Times, March 25, 2010.

${ }^{21}$ Katya Gibel Mevorach, "Race, Racism, and Academic Complicity," American Ethnologist 34, no. 2 (2007): 238.

22 Marisa Alicea and Barbara Kessel, "The Socially Awkward Question: A Simulation Exercise for Exploring Ethnic and Racial Labels," Teaching Sociology 25, no. 1 (1997): 65-71; Khanna and Harris, "Teaching Race as a Social Construction."

${ }^{23}$ Omi and Winant, Racial Formation in the United States, 4.

24 Moises Velasquez-Manoff, "Opinion | What Biracial People Know," The New York Times, March 4, 2017, sec. Opinion,

https://www.nytimes.com/2017/03/04/opinion/sunday/wh at-biracial-people-know.html.

25 Anthony G. Greenwald and Linda Hamilton Krieger, "Implicit Bias: Scientific Foundations," California Law Review 94, no. 4 (2006): 946, https://doi.org/10.2307/20439056; R. Richard Banks, 
Jennifer L. Eberhardt, and Lee Ross, "Discrimination and Implicit Bias in a Racially Unequal Society," California Law Review 94, no. 4 (2006): 1169-90, https://doi.org/10.2307/20439061; Alexander R. Green et al., "Implicit Bias among Physicians and Its Prediction of Thrombolysis Decisions for Black and White Patients," Journal of General Internal Medicine 22, no. 9 (September 1, 2007): 1231-38, https://doi.org/10.1007/s11606-0070258-5; Tobias Brosch, Eyal Bar-David, and Elizabeth A. Phelps, "Implicit Race Bias Decreases the Similarity of Neural Representations of Black and White Faces," Psychological Science 24, no. 2 (February 1, 2013): 16066, https://doi.org/10.1177/0956797612451465; Natasha Warikoo et al., "Examining Racial Bias in Education: A New Approach," Educational Researcher 45, no. 9 (December 1, 2016):

508-14, https://doi.org/10.3102/0013189X16683408; Justin D. Levinson, Huajian Cai, and Danielle Young, "Guilty by Implicit Racial Bias: The Guilty/Not Guilty Implicit Association Test," Ohio State Journal of Criminal Law 8, no. 1 (2010): 187-208.

${ }^{26}$ Nicholas Kristof, "Opinion | Our Racist, Sexist Selves," The New York Times, April 6, 2008, sec. Opinion, https://www.nytimes.com/2008/04/06/opinion/06kristof.ht ml; Nicholas Kristof, "Opinion | Our Biased Brains," The New York Times, May 7, 2015, sec. Opinion, https://www.nytimes.com/2015/05/07/opinion/nicholaskristof-our-biased-brains.html.

${ }^{27}$ Laurie A. Rudman, "Social Justice in Our Minds, Homes, and Society: The Nature, Causes, and Consequences of Implicit Bias," Social Justice Research 17, no. 2 (June 2004): 137.

${ }^{28}$ Arusha Gordon and Ezra D. Rosenberg, "Barriers to the Ballot Box: Implicit Bias and Voting Rights in the 21st Century," Michigan Journal of Race \& Law 21, no. 1 (2015): 51; Warikoo et al., "Examining Racial Bias in Education," 512; L. Elizabeth Sarine, "Regulating the Social Pollution of Systemic Discrimination Caused by Implicit Bias," California Law Review 100, no. 5 (2012): 1359-99.

${ }^{29}$ Barbara Jeanne Fields, "Slavery, Race and Ideology in the United States of America," New Left Review, I, no. 181 (1990): 95-118; Yaba Blay, (1)Ne Drop: Shifting the Lens on Race (BLACKprint Press, 2013).

30 Eva Marie Garroutte, Real Indians: Identity and the Survival of Native America (Berkeley: University of California Press, 2003), 45.

${ }^{31}$ Alisha Roopchand, "Dear Yuri: A Thank You and Tribute to Yuri Kochiyama," Tapestries: Interwoven Voices of Local and Global Identities 4, no. 1 (Spring 2015): 1-6; Rea Tajiri and Pat Saunders, Yuri Kochiyama: Passion for Justice | CAAM Home (Center for Asian American Media, 1993), http://caamedia.org/films/yuri-kochiyama-passionfor-justice/.

32 Matthew Garcia, "The Importance of Being Asian: Growers, the United Farm Workers and the Rise of Colorblindness," in Racial Formation in the Twenty-First Century (Berkeley: University of California Press, 2012), http://site.ebrary.com/id/10577732; Natsu Saito, "Model
Minority, Yellow Peril: Functions of Foreignness in the Construction of Asian American Legal Identity," Asian American Law Journal 4, no. 1 (January 1, 1997): 71, https://doi.org/10.15779/Z38FZ9V.

33 For media, photographs and primary sources about Australian Freedom Rides: the Australian Institute of Aboriginal and Torres Strait Islander Studies https://aiatsis.gov.au/exhibitions/1965-freedom-ride. Rolf de Heer, The Tracker, 2002; Paul Kelly, From Little Things Big Things Grow, Comedy, 1991; admin, "Bringing Them Home: The 'Stolen Children' Report (1997)," December 14, 2012, http://www.humanrights.gov.au/ourwork/aboriginal-and-torres-strait-islander-social-

justice/publications/bringing-them-home-stolen.

34 Mohamed Adhikari, Burdened by Race: Coloured Identities in Southern Africa (Juta and Company Ltd, 2009).

35 Evelyn Nakano Glenn, "Yearning for Lightness: Transnational Circuits in the Marketing and Consumption of Skin Lighteners," Gender \& Society 22, no. 3 (June 1, 2008): 281-302, https://doi.org/10.1177/0891243208316089; L. Ayu Saraswati, "'Malu': Coloring Shame and Shaming the Color of Beauty in Transnational Indonesia," Feminist Studies 38, no. 1 (2012).

36 Priya Kandaswamy, "Beyond Colorblindness and Multiculturalism: Rethinking Anti-Racist Pedagogy in the University Classroom," Radical Teacher, no. 80 (2007): 11, https://doi.org/10.2307/20710420.

${ }^{37}$ Kandaswamy, 11.

${ }^{38}$ Shaun R. Harper, "Am I My Brother's Teacher? Black Undergraduates, Racial Socialization, and Peer Pedagogies in Predominantly White Postsecondary Contexts," Review of Research in Education 37 (2013): 183-211; Enid Logan et al., "Double Consciousness: Faculty of Color Teaching Students of Color About Race," in Teaching Race and AntiRacism in Contemporary America: Adding Context to Colorblindness (Springer Science and Media, 2014).

${ }^{39}$ Logan et al., "Double Consciousness: Faculty of Color Teaching Students of Color About Race," 124.

40 Rita Kholi, "Breaking the Cycle of Racism in the Classroom: Critical Race Reflections for Future Teachers of Color," Teacher Education Quarterly 35, no. 4 (Fall 2008): 177-88.

${ }^{41}$ Richard Smith and Lauren Dundes, "Reticent on Race: Promoting Constructive Discussions about Race in a College Classroom," Race and Pedagogy Journal: Teaching and Learning for Justice 1, no. 3 (May 17, 2016): 17, https://soundideas. pugetsound.edu/rpj/vol1/iss3/2. In this qualitative study of a successful race and ethnicity course, although the students of color were aligned with the White students in praising the course, they located their appreciation of the course in the experience of watching White students' racial consciousness grow, not in their own intellectual expansion. 
42 Deanna Blackwell, "Sidelines and Separate Spaces: Making Education Anti-Racist for Students of Color," Race Ethnicity and Education 13, no. 4 (2010): 473-94.

43 Walter Johnson, "Brute Ideology," Dissent 61, no. 4 (September 19, 2014): 127-32, https://doi.org/10.1353/dss.2014.0090.

${ }^{44}$ Michael A. Gomez, Exchanging Our Country Marks: The Transformation of African Identities in the Colonial and Antebellum South (University of North Carolina Press, 2000).

${ }^{45}$ Gomez, 27.

${ }^{46}$ Shaun R Harper, "Race without Racism: How Higher Education Researchers Minimize Racist Institutional Norms," The Review of Higher Education 36, no. 1 (2012); Ibram X. Kendi, "Why the Academic Achievement Gap Is a Racist Idea - AAIHS," October 20, 2016, http://www.aaihs.org/why-the-academic-achievementgap-is-a-racist-idea/; Moulder, "Teaching about Race and Ethnicity."

47 Ibram X. Kendi, Stamped From the Beginning: The Definitive History of Racist Ideas in America, (New York: Nation Books, 2016) 11.

48 Tamar Szabó Gendler, "On the Epistemic Costs of Implicit Bias," Philosophical Studies: An International Journal for Philosophy in the Analytic Tradition 156, no. 1 (2011): 37. 